\title{
DIVERSI SEBAGAI WUJUD KEBIJAKAN PEMIDANAAN DALAM SISTEM PERADILAN PIDANA ANAK DI INDONESIA
}

\author{
Ani Purwati dan Arief Syahrul Alam
}

\author{
Fakultas Hukum, Universitas Wijaya Putra \\ anipurwati1982@gmail.com dan syarulalam@uwp.ac.id.
}

\begin{abstract}
Abstrak
The diversion, a criminalization policy of restorative justice in the system of juvenile justice in Indonesia under the Law No. 11 Year 2012 on Child Criminal Justice System, is an alternative solution of juvenile criminal cases and to reduce the number of recidivist criminal assault of children in Indonesia. Indonesian policy in setting diversion to children cases using penal procedure is in accordance with international instruments, namely the Convention on the Rights of the Child (CRC), Beijing Rules, Riyadh Guidelines, and the Tokyo Rules. Moreover, the restorative justice should not conflict with the philosophical, political, cultural, normative values of Pancasila as supporting norm in social policy and law enforcement in criminal law reform. The approach used in this study using statute and conceptual approach to maximize the implementation of diversion in every stage of investigation, prosecution and trial. The research objective is reviewing the judicial review of Law No. 11 In 2012, which having conflict with the norm in establishing a referral system in handling children cases effectively, either for Law Enforcement, Network Protection or Treatment of Children in East Java.
\end{abstract}

Kebijakan pemidanaan keadilan restoratif dalam sistem peradilan pidana anak di Indonesia sesuai Undang-Undang No. 11 Tahun 2012 Tentang Sistem Peradilan Pidana Anak yaitu Diversi sebagai alternatif penyelesaian perkara pidana anak dan mengurangi jumlah residivis perkara tindak pidana anak di Indonesia. Pengaturan diversi terhadap anak yang berkonflik dengan hukum dengan menggunakan sarana penal pada kebijakan kriminal di Indonesia sesuai dengan instrumen Internasional yaitu Konvensi Hak Anak (KHA), Beijing Rules, Riyadh Guidelines, Tokyo Rules pendekatan keadilan restoratif yang tidak bertentangan dengan nilai filosofis, politik, dan kultural, aspek normatif dengan nilai-nilai pancasila sebagai sarana pendukung kebijakan sosial, kriminal dan penegakan hukum dalam pembaharuan hukum pidana. pendekatan yang digunakan dalam penelitian ini menggunakan pendekatan perundang-undangan (statue approach), pendekatan konseptual (conceptual approach) dengan memaksimalkan pelaksanaan diversi disetiap tahapan penyidikan, penuntutan dan pengadilan. Tujuan penelitian melakukan judicial review Undang-undang No. 11 Tahun 2012 yang terjadi konflik norma dalam, membangun sistem reveral dalam penanganan anak konflik hukum secara efektif baik Aparat Penegak Hukum, Jaringan Perlindungan dan Penanganan Anak di Jawa Timur.

Kata Kunci: Keadilan Restoratif, Sistem Peradilan Pidana Anak, Diversi 
Permasalahan anak yang berkonflik dengan hukum selanjutnya disebut AKH harus membutuhkan suatu penanganan yang serius, secara internasional dan nasional tidak hanya jumlahnya kejahatan yang meningkat tetapi juga kualitas kejahatannya. Hal tersebut diperlukan upaya pencegahan dan penanggulangan tindak pidana anak melalui penyelenggaraan sistem peradilan pidana anak. Pembaharuan hukum pidana anak didalam kebijakan kriminal merupakan bagian intergral dari upaya perlindungan masyarakat dan pencapaian kesejahteraan masyarakat. Kebijakan kriminal menggunakan sarana penal di Indonesia terwujud dalam Undang-undang No.11 Tahun 2012 tentang Sistem Peradilan Pidana Anak yang wajib mengutamakan pendekatan keadilan restoratif yaitu diversi. Secara filosofis pengaturan ini memiliki kesesuaian dengan nilai-nilai pancasila. Sedangkan secara yuridis pengaturan ini merupakan respon atas keberlakuan berbagai instrumen perlindungan hak anak nasional maupun internasional. Hal ini diharapkan mampu menghindari stigma dan labeling selama proses peradilan sampai penjatuhan pemidanaan terhadap anak. Sehingga tidak muncul pelabelan yang berkelanjutan, rasa rendah diri, dan rasa bersalah pada diri anak. ${ }^{1}$

Upaya menghindari dampak negatif selama proses peradilan pidana anak yang diatur dalam United Nations Standard Minimum Rules For The Administration Of Juvenile Justice (The Beijing Rules) memberikan otoritas kewenangan aparat penegak hukum untuk mengambil tindakantindakan kebijaksanaan dalam menangani atau menyelesaikan masalah pelanggar anak dengan tidak mengambil jalan formal antara lain menghentikan atau tidak meneruskan dari proses peradilan atau mengembalikan dan menyerahkan kembali kepada masyarakat dan bentuk-bentuk kegiatan pelayanan sosial lainnya. ${ }^{2}$ Meskipun telah diakui baik secara

${ }^{1}$ Apong Herlina, Perlindungan Terhadap Anak Yang Berhadapan Dengan Hukum Dengan Manual Pelatihan Untuk Polisi (Jakarta: Polri dan Unicef, 2004), h.101

${ }^{2}$ Barda Nawawi, Beberapa Aspek Kebijakan Penegakan dan Pengembangan Hukum Pidana (Bandung: P.T Citra nasional maupun internasional, pelaksanaan diversi belum dilaksanakan secara maksimal. Masih terdapat beberapa persoalan seperti: Pertama, Anak berkonflik dengan hukum masih menjalani proses peradilan pidana dan dijatuhi sanksi perjara dengan jumlah cukup tinggi. ${ }^{3} \mathrm{Kedua}$, terbatasnya sarana dan prasarana dalam perlindungan AKH selama proses peradilan (pra maupun pasca putusan pengadilan) dan minimnya jumlah Lembaga Pembinaan Khusus Anak (LPKA) di tiap-tiap provinsi sehingga belum sepenuhnya dipisahkan antara LPKA dan Lapas Dewasa, ${ }^{4}$ dan Rutan Anak. Ketiga, kondisi riil dilapangan data diversi belum tersistematis mulai dari tingkat kepolisian mulai dari Polsek sampai Polrestabes, ${ }^{5}$ Bapas (Balai Pemasyarakatan), Keempat,belum nomenklatur yang mengatur tentang Lembaga Penempatan Anak Sementara (LPAS), ${ }^{6}$ Kelima, Koordinasi antar aparat penegak hukum (Kepolisian, Kejaksaan, Mahkamah Agung,

Aditya Bakti, 1999), h.165.

${ }^{3}$ Jumlah Anak Konflik Hukum (AKH) di Indonesia masih tinggi, pada tahun 2015 tercatat 2.621 anak berkonflik dengan hukum. Data Terakhir Klasifikasi Narapidana Anak Perkanwil (Online) (dapat diakses di http://smslap.ditjenpas.go.id/public/arl/current/ monthly/year/2015/month/1, tanggal 15 Januari 2015).

${ }^{4}$ Sekitar 2.408 narapidana anak masih berada di LAPAS dewasa dari total narapidana anak berjumlah 3.228 artinya baru $25 \%$ narapidana masih ditempatkan di lapas anak. Lihat Mardiharto Tjokrowasito dkk., Background Study RPJMN2015-2019 Bidang Pembangunan Hukum Nasional (Jakarta: Bappenas, 2013),h. 61

${ }^{5}$ Pendataan belum diversi masih belum tersistematis dari laporan Polsek untuk menyerahkan data, dan menurut beliau yang sering sekali dengan menggunakan SP3, Bapas Kelas 1 Surabaya sudah melakukan rekapitulasi namun pihak kepolisian, kejaksaan, dan tingkat pengadilan dari sisi laporan administrasi diversi belum tersistematis sehingga data kompilasi diversi sangat berbeda jumlah yang dilakukan. Data Bapas Kelas 1 Surabaya menunjukkan bahwa Diversi Anak Kembali Ke Orang Tua pada tahun 2012 sejumlah 34 kasus, pada 2013 sejumlah 10 kasus dan pada tahun 2014 sejumlah 60 kasus. Sementara Putusan Pidana Penjara pada tahun 2012 sejumlah 90 kaus, pada tahun 2013 sejumlah 110 kasus dan pada tahun 2014 sejumlah 68 kasus. AKP. Sherly Maculata, wawancara, Surabaya 26 Maret 2015

${ }^{6}$ LPAS hampir sama kondisinya dengan Rumah Tahanan (RUTAN) masih belum riil dalam pelaksanaannya. Nadhif Ulfa, wawancara, Surabaya 26 Maret 2015 
Kementerian Hukum dan HAM, Kementerian Sosial, Kementerian Pemberdayaan Perempuan dan Anak, Kementerian Pendidikan, dan Kementerian Kesehatan masih bersifat parsial, sektoral dalam melaksanakan kebijakan dan kewenangannya. Pengawasan untuk AKHyang dijatuhi putusan berupa tindakan dibawah pengawasan BAPAS juga belum berfungsi dengan baik karena kurangnya sumber daya manusia Petugas Kemasyarakatan Balai Pemasyarakatan (PK BAPAS) di Indonesia. Lembaga-lembaga yang diamanatkan dalam Undang-Undang No.11 Tahun 2012 yaitu lembaga pembinaan khusus anak (LPKA), Lembaga penempatan anak sementara (LPAS) dan Lembaga penyelenggara kesejahteraan sosial (LPKS) juga belum ada di beberapa daerah. ${ }^{7}$ Berdasarkan berbagai persoalan di atas penelitian ini bertujuan mengkaji tentang pengaturan kebijakan pemidanaan keadilan restoratif terhadap perlindungan hak anak dalam sistem peradilan pidana Indonesia serta implementasi diversi dalam penanggulangan tindak pidana anak.

\section{Diversi Sebagai Wujud Keadilan Restoratif}

Sistem pemidanaan yang selama ini dijalankan dirasa masyarakat belum efektif dan menimbulkan berbagai persoalan. Penjatuhan pidana penjara belum berfungsi secara maksimal menimbulkan efek jera. Selain itu, pidana penjara merusak hubungan terpidana kepada keluarga maupun masyarakat. ${ }^{8}$ Persoalan ini memunculkan gagasan tentang keadilan restoratif sebagai ganti dari keadilan restitusi dan retribusi yang selama ini dipraktikkan dalam sistem pemidanaan. Undang-Undang No. 11 Tahun 2012 Sistem Peradilan Pidana Anak mendefinisikan keadilan restoratif sebagai penyelesaian perkara tindak pidana dengan

${ }^{7}$ Data pengajuan anggaran pelaksanaan diversi di Kanwil Departemen Hukum dan HAM Surabaya tidak seimbang dengan jumlah diversi yang riil terjadi. Nadhif Ulfa, wawancara, Surabaya 2 Mei 2015

${ }^{8}$ DS. Dewi dan Fatahillah A. Syukur, Mediasi Penal: Penerapan Restorative Justice di Pengadilan Anak Indonesia (Depok: Indie Publishing, 2011), h. 22 melibatkan pelaku, korban, keluarga pelaku/ korban, dan pihak lain yang terkait untuk bersama-sama mencari penyelesaian yang adil dengan menekankan pemulihan kembali pada keadaan semula, dan bukan pembalasan. Helen Cowie menyatakan bahwa keadilan restoratif berpijak pada konsep komunitas yang peduli dan inklusif. Para pihak terkait, seperti pelaku, korban, keluarga, dan para stakeholders komunitas akan secara bersama-sama memperbaiki kerusakan, memulihkan kualitas hubungan, dan memfasilitasi reintegrasi para pihak yang berkonflik. ${ }^{9}$ John Braithwaite menyatakan bahwa keadilan restotatif mendorong integrasi dan menghindari stigmatisasi, memelihara rasa tanggung jawab penyesalan, dan pemaafan. ${ }^{10}$ Dengan kata lain keadilan restoratif merupakan alternatif atas keadilan tradisional yang berpusat pada penghukuman (punishment) menuju kepada keadilan masyarakat (community justice) yang berpusat pada pemulihan.

Tony F. Marshall menyatakan bahwa restorative Justice is aprocess whereby all the parties with a stake in a particular offence come together to resolve collectively how to deal with the after math of the offence and its implication for the future. Sedangkan menurut John Bradford Braithwaite mengungkapkan bahwa keadilan restoratif mampu mereformasikan sistem peradilan bersifat responsif sehingga peraturan hukum mempunyai nilai untuk menciptakan keadilan bagi diri sendiri, masyarakat dan warga negara. Keadilan restoratif menurut Geogre Pavling merupakan bentuk keadilan yang menekankan perbaikan atas akibat yang timbul dari suatu tindak pidana dengan mendayagunakan proses restoratif serta memperhatikan semua kepentingan yang terlibat baik kepentingan korban, pelaku maupun masyarakat untuk memperbaiki dirinya sendiri maupun pihak lainnya. Menurut Llewellyn dan Howse keikhlasan hati dan kejujuran merupakan komponen utama dalam menyelesaikan perkara

${ }^{9}$ Hadi Supeno, Kriminalisasi Anak Tawaran Gagasan Radikal Peradilan Anak Tanpa Pemidanaan (Jakarta: Gramedia Pustaka Utama, 2010), h. 196 h. 30

${ }^{10}$ DS. Dewi dan Fatahillah A. Syukur, Mediasi Penal, 
pidana berdasarkan keadilan restoratif. ${ }^{11} \mathrm{Jim}$ Consedine salah seorang pelopor keadilan restoratif dari New Zealand berpendapat konsep keadilan retributif dan restitutif yang berlandaskan hukuman, balas dendam terhadap pelaku, pengasingan, perusakan harus digantikan dengan keadilan restoratif yang berdasarkan rekonsiliasi, pemulihan korban, reintergrasi dalam masyarakat, pemaafan dan pengampunan. Dean E. Peachey menggambarkan perbedaan ketiga konsep keadilan di atas sebagai berikut ${ }^{12}$ :

Tabel 1. Perbandingan Keadilan Dalam Pemidanaan

\begin{tabular}{|c|c|c|c|c|}
\hline No. & $\begin{array}{c}\text { Per- } \\
\text { bedaan }\end{array}$ & Restitusi & Retributif & Restoratif \\
\hline 1. & $\begin{array}{l}\text { Landasan } \\
\text { Filosofi }\end{array}$ & $\begin{array}{l}\text { Memperbaiki } \\
\text { kesalahan } \\
\text { korban } \\
\text { dengan } \\
\text { mengganti } \\
\text { atau } \\
\text { memperbarui }\end{array}$ & $\begin{array}{l}\text { Mencapai } \\
\text { keadilan } \\
\text { dengan } \\
\text { memberi } \\
\text { balasan } \\
\text { atas derita/ } \\
\text { sakit yang } \\
\text { ditimbulkan }\end{array}$ & $\begin{array}{l}\text { Pemberian } \\
\text { maaf } \\
\text { sebagai } \\
\text { dasar } \\
\text { memperbaiki } \\
\text { hubungan } \\
\text { antar } \\
\text { manusia }\end{array}$ \\
\hline 2. & Cara & $\begin{array}{l}\text { Korban } \\
\text { menerima } \\
\text { ganti rugi }\end{array}$ & $\begin{array}{l}\text { Pelaku } \\
\text { dijatuhi } \\
\text { hukuman } \\
\text { yang } \\
\text { setimpal } \\
\text { atau lebih } \\
\text { berat }\end{array}$ & $\begin{array}{l}\text { Pelaku } \\
\text { menyesali, } \\
\text { perbuatan, } \\
\text { berjanji tidak } \\
\text { mengulangi } \\
\text { (dengan } \\
\text { memperbaiki } \\
\text { ganti rugi } \\
\text { yang } \\
\text { diperlukan) }\end{array}$ \\
\hline 3. & Fokus & Korban & Pelaku & $\begin{array}{l}\text { Korban dan } \\
\text { Pelaku }\end{array}$ \\
\hline
\end{tabular}

Sebagai wujud pelaksanaan keadilan restoratif dalam penanganan perkara pidana dikenal istilah mediasi penal atau Mediation in Criminal Cases atau Mediation in Penal Matters (Inggris), Strabemiddeling (Belanda) dan Der Aubergerichliche Tatausgleich (Jerman). Mediasi adalah proses negoisasi pemecahan masalah dimana pihak luaryang tidak memihak (impartial) bekerjasama dengan pihak yang bersengketa untuk mencari kesepakatan bersama. Mediator tidak berwenang memutuskan sengketa,

\footnotetext{
${ }^{11}$ Marliana, Peradilan Pidana Anak di Indonesia Pengembangan Konsep Diversi dan Restoratif Justice (Bandung: Refika Aditama, 2012), h. 25 h. 26

${ }^{12}$ DS. Dewi dan Fatahillah A. Syukur, Mediasi Penal,
}

tetapi hanya membantu para pihak untuk menyelesaikan persoalan yang dikuasakan kepadanya. ${ }^{13}$ Sedangkan yang dimaksud dengan mediasi penal, menurut Umbreit adalah:

A process that gives victims of property crimes or minor assault the opportunity to meet the perpetrators of these crimes in as afeand structured setting, with the goal of holding the offenders directly accountable while providing important assistance and compensation to the victims. Assisted by atrained mediator, the victim is able to let the offender know how the crime affected him or her, receive answers to questions, and be directly involved in developing arestitution plan for the offender to be accountable for the loss or damage caused. ${ }^{14}$

Mediasi penal dapat digunakan untuk menangani perkara yang melibatkan orang dewasa maupun anak-anak. Model ini dapat diterapkan disemua perkara pidana mupun terbatas pada perkara tertentu saja seperti tindak pidana yang dilakukan oleh anakanak, tindak pidana ringan, pelaku pemula. Mediasi penal diharapkan mampu mengurangi penumpukan perkara, mengurangi beban biaya, sederhana dan waktu yang dibutuhkan relatif singkat. Serta memberikan akses luas kepada para pihak untuk memperoleh keadilan. Mediasi penal dapat menjadikan pelaku lebih bertanggung jawab, terhindar peminggiran dan stigma negatif masyarakat. Selain itu, korban dapat mendengar alasan pelaku melakukan tindakannya, menolong pelaku bila memungkinkan, berkomunikasi dengan pelaku, memastikan pelaku tidak mengulangi perbuatannya. ${ }^{15}$

Di Indonesia, praktik mediasi penal dalam tindak pidana yang melibatkan anak-anak disebut dengan istilah diversi. Menurut Henry

\footnotetext{
${ }^{13}$ Mediasi biasa dilakukan untuk menyelesaikan perkara perdata. Meskipun demikian, dalam perkembangannya mediasi juga diintegrasikan dalam perkara pidana. Khotibul Umam, Penyelesaian Sengketa di Luar Pengadilan. (Yogyakarta : Pustaka Yustisia, 2010), h. 10 h. 78

${ }^{14}$ DS. Dewi dan Fatahillah A. Syukur, Mediasi Penal, h. 87
} 
Campbell Black diversi adalah a disposition of criminal defendant either before to after adjudication of guilt in wich the court direct the defendant to participation in a work educatinational program as part of probation. Bynum dan Thompson mendefinisikan diversi sebagai an attempt to divert, or channel out, youthful offenders from the juvenile justice system. Dalam Undang-Undang Sistem Peradilan Pidana Anak dinyatakan bahwa diversi adalah pengalihan penyelesaian perkara Anak dari proses peradilan pidana ke proses di luar peradilan pidana. Dalam United Nations Standar Minimum Rules for the Administration of Juvenile Justice dinyatakan bahwa diversi merupakan proses melimpahkan anak yang berkonflik dengan hukum dari sistem peradilan pidana kepada sistem informal seperti mengembalikan kepada lembaga sosial masyarakat, baik pemerintah maupun swasta. Tindakan ini dilakukan untuk menghadri efek negatif terhadap jiwa dan perkembangan anak. ${ }^{16}$ Dalam konteks keadilan restoratif, diversi merupakan alternatif dari sistem peradilan pidana yang dilaksanakan sekarang. Meskipun masyarakat harus berdasarkan hukum, akan tetapi harus ada fleksibilitas untuk menyesuaikan diri degan kompleksitas permasalahan hukum yang diharapi sekarang ini. ${ }^{17}$

\section{Tujuan dan Batasan Diversi}

Diversi memberikan kesempatan kepada pelaku tindak pidana untuk mengindari penuntutan dan/atau penahanan, mendapat bantuan kesehatan, konseling, pendidikan, dan pelatihan ketrampilan. ${ }^{18}$ Sementara itu, Pasal 6 Undang-Undang No. 11 Tahun 2012 menyatakan bahwa pelaksanaan diversi terhadap anak yang berkonflik dengan hukum bertujuan untuk : a. mencapai perdamaian antara korban dan Anak; b. menyelesaikan perkara Anak di luar proses peradilan; c. menghindarkan Anak

\footnotetext{
${ }^{16}$ Marliana, Peradilan Pidana Anak, h. 19 h. 51

${ }^{17}$ DS. Dewi dan Fatahillah A. Syukur, Mediasi Penal, h. 52

${ }^{18}$ DS. Dewi dan Fatahillah A. Syukur, Mediasi Penal,
}

dari perampasan kemerdekaan; d. mendorong masyarakat untuk berpartisipasi; dan e. menanamkan rasa tanggung jawab kepada Anak. Dalam penjelasan umum UndangUndang ini dinyatakan bahwa kebijakan tentang diversi untuk mewujudkan keadilan restoratif dimaksudkan untuk menghindari dan menjauhkan Anak dari proses peradilan sehingga dapat menghindari stigmatisasi terhadap nak yang berhadapan dengan hukum dan diharapkan Anak dapat kembali ke dalam lingkungan sosial secara wajar. Dalam Pasal 7 ayat (1) dinyatakan bahwa Pada tingkat penyidikan, penuntutan, dan pemeriksaan perkara Anak di pengadilan negeri wajib diupayakan Diversi. Sementara pada ayat (2) diberikan batasan bahwa diversi sebagaimana dimaksud pada ayat (1) dilaksanakan dalam hal tindak pidana yang dilakukan: a) diancam dengan pidana penjara di bawah 7 (tujuh) tahun; dan b) bukan merupakan pengulangan tindak pidana.

\section{Pengaturan Keadilan Restoratif Bagi Anak}

Perlindungan hak-hak anak telah diatur dalam hukum Internasional diantaranya Convention on the Rights of the Child tahun 1989 Konvensi tentang Hak-hak Anak (KHA), The United Nations Guiedlines for the Prevention of Juvenile Deliquency (The Riyadh Guildlines) atau Pedoman PBB dalam rangka pencegahan tindak pidana anak, disahkan dan dinyatakan dalam Resolusi Majelis Umum PBB No.45/112 tanggal 14 Desember 1990, The United Nations Standard Minimum Rules for the Administration of Juvenile Justice (The Beijing Rules) atau Peraturan Minimum Standar tentang administrasi peradilan bagi anak disahkan melalui Resolusi Majelis PBB No.40/33tanggal 29 November 1985) dan The United Nations Rules for the Protection of Juvenile Deprived of Their Liberty atau Perlindungan Anak yang Kehilangan Kebebasannya disahkan melalui Resolusi Majelis PBB No.45/113 tanggal 14 Desember 1990.

Perlindungan khusus anak yang berhadapan dengan hukum maupun anak korban tindak pidana di Indonesia telah diratifikasi melalui Keppres 36 tahun 1990 (KHA) yang dikategorikan 
anak dalam situasi khusus (Children In Need Of Special Protection (CNSP)) yang diatur dalam pasal 1 ayat (15) dan Pasal 59 UU No.23 Tahun 2002 Tentang Perlindungan Anak. Sejalan dengan prinsip CRC (Convention of the Rights of the Child), UUNo. 23 Tahun 2002 Tentang Perlindungan Anak dan SKB (Surat Keputusan Bersama), Strategi Nasional Akses Terhadap Keadilan (STRANAS) dan BAPENAS 2009 juga menekankan penyelesaian secara restoratif. Namun dalam STRANAS diakui kelemahan dalam sistem perlindungan anak yaitu ketidakjelasan mekanisme acara perlindungan ABDH. Hal ini disebabkan mekanisme dan hukum acaranya diserahkan pada sistem peradilan umum yang menggunakan pendekatan Retributive Justice (penghukuman pelaku).

Sebagai tindak lanjut Stranas Akses Keadilan, Presiden telah menerbitkan Instruksi Presiden No.3 Tahun 2010. Tentang Program Pembangunan yang berkeadilan yang memerintahkan kementerian dan lembaga terkait untuk mengembangkan Standard Operating Procedures (SOP) penanganan $\mathrm{ABDH}$ dengan pendekatan restorative justice dan pengembangan sosialisasi serta pemberian pemahaman kepada aparatur pengadilan dan penegak hukum lainnya. Pengawasan masyarakat sangat dibutuhkan untuk memantau pelaksanaan Inpres tersebut, khususnya menyangkut pelaksanaan keadilan restoratif dalam $\mathrm{ABDH}$.

Pembaharuan hukum pidana (penal reform) merupakan bagian dari kebijakan atau politik hukum pidana. Makna dan hakikat dari pembaharuan hukum pidana berkaitan dengan aspek: a) Kebijakan sosial (sosial policy) dalam pembaharuan hukum pidana; padahakikatnya merupakan bagian dari upaya untuk mengatasi masalah-masalah sosial dalam rangka mencapai tujuan nasional; b) Kebijakan kriminal (criminal policy) dalam pembaharuan hukum pidana; pada hakikatnya bagian dari upaya perlindungan masyarakat atau penanggulangan kriminal yang merupakan usaha yang rasional dari masyarakat sebagai reaksi terhadap kejahatan; c) Kebijakan penegakan hukum (law enforcement policy) dalam pembaharuan hukum pidana;pada hakikatnya merupakan bagian dari upaya memperbaharui subtansi hukum dalam rangka lebih mengefektifkan penegakan hukum.

\section{Variasi Penerapan Keadilan Restoratif di Bebepa Negara}

Keadilan restoratif telah dipraktikkan disejumlah negara, antara lain ${ }^{19}$ : Pertama, Informal Mediation, Model ini dilaksanakan oleh personil peradilan pidana (criminal justice personel) dalam tugas normalnya yaitu dapat dilakukan oleh JPU (Jaksa Penuntut Umum) dengan mengundang para pihak untuk melakukan penyelesaian informal dengan tujuan melanjutkan penuntutan apabila tercapai kesepakatan;dapat dilakukan oleh pekerja sosial atau penjabat pengawas (probation officer) oleh penjabat polisi atau hakim; Kedua, Traditional Village or Tribal Moots, Pada model ini seluruh anggota masyarakat bertemu untuk memecahkan konflik kejahatan antar warganya: a) Model ini cocok diterapkan di beberapa negara yang kurang maju dan di wilayah pedesaan/pedalaman; b) Model ini lebih memilih keuntungan bagi masyarakat luas; c) Model ini mendahului hukum barat dan telah memberikan inspirasi modern. Progam mediasi modern sering mencoba memperkenalkan berbagai keuntungan dari pertemuan suku (tribalmoots) dalam benttuk yang disesuaikan dengan struktur masyarakat modern dan hak-hak individu yang diakui menurut hukum;

Ketiga, Victim Offender Mediation, Mediasi antara korban dan pelaku merupakan model yang sering ditemukan. Model ini melibatkan berbagai pihak yang bertemu dengan dihadiri oleh mediator yang ditunjuk. Banyak variasi dari model ini yang dapat berasal dari penjabat formal, mediator independen atau kombinasi. Mediasi ini dapat diadakan pada setiap tahapan proses baik kebijaksanaan polisi, tahap penuntutan, pemidanaan dan pelaksanaan pemidanaan. Model ini diterapkan untuk semua tipe pelaku tindak pidana; ada yang khusus untuk anak, ada yang tipe tindak pidana

\footnotetext{
${ }^{19}$ Marliana, Peradilan Pidana Anak, h. 181-195
} 
tertentu (misalnya pengutilan, perampokan dan tindak kekerasan). Ada yang terutama ditujukan pada pelaku anak, pelaku pemula dan untuk delik-delik berat dan bahkan untuk residivis. Keempat, Reparation Negotiation Progammes, Model ini semata-mata untuk menaksir/menilai kompensasi atau perbaikan yang harus dibayar oleh pelaku tindak pidana kepada korban,biasanya pada pemeriksaan dipengadilan. Progam ini tidak berhubungan dengan rekonsiliasi antara para pihak, tetapi hanya berkaitan dengan perencanaan perbaikan materiil. Dalam model ini pelaku tindak pidana dapat dikenakan progam kerja agar dapat menyimpan uang untuk membayar ganti rugi/ kompensasi.

Kelima, Community Panels Or Court, Model ini merupakan progam untuk membelokkan kasus pidana dari penuntutan atau peradilan pada prosedur masyarakat yang lebih fleksibel atau informal dan sering melibatkan unsur mediasi atau negosiasi. Keenam, Family and Community Group Conferences, Model ini telah dikembangkan di Negara Australia dan New Zealand yang melibatkan partisipasi masyarakat dalam Sistem Peradilan Pidana (SPP). Tidak hanya melibatkan korban dan pelaku tindak pidana, tetapi juga keluarga masyarakat lainnya, penjabat tertentu (polisi, dan hakim anak) dan para pendukungkorban. Pelaku dan keluarganya diharapkan menghasilkan kesepakatan yang komperhensif dan memuaskan korban serta dapat membantu untuk menjaga si pelaku keluar dari persoalan yang berikutnya.

\section{Implementasi Diversi di Beberapa Negara}

Kebijakan pemidanaan terhadap anakanak dapat dilakukan melalui berbagai cara, antara lain: 1) Peringatan, diberikan untuk pelanggaran ringan. Dengan peringatan ini, maka si pelaku meminta maaf pada korban dan polisi mencatat detil kejadian dan mencatat dalam arsip kantor polisi; 2) Diversi informal, diterapkan terhadap pelanggaran ringan yang dirasakan kurang pantas jika sekedar peringatan namun membutuhkan intervensi yang komperhensif. Haruslah dipastikan bahwa pelaku anak akan bertanggungjawab, mengakui kebutuhan-kebutuhan korban dan anak serta apabila dimungkinkan orang tua dimintai bertanggungjawab atas kejadian tersebut; 3) Diversi Formal, dilakukan jika diversi informal tidak dapat dilakukan, tetapi tidak memerlukan intervensi pengadilan. Misalnya Musyawarah Kelompok Keluarga (FGC), Musyawarah Keadilan Restoratif (Restorative Justice Conference) dan Musyawarah Masyarakat (Community Conferencing).

Diversi dapat dilakukan pada tahap penyidikan, penuntutan, dan tahap pemeriksaan pengadilan. Implementasi diversi ini disatu pihak melindungi anak, dimana pihak masyarakat atau korbanpun tetap terlindungi. Perlindungan terhadap korban pun tetap ada jika melihat syarat-syarat dan progam-progam diversi yang harus dilakukan pada anak. Namun demikian tujuan utama implementasi diversi adalah menghindari terhadap efek negatif proses peradilan pidana, dan digantikan dengan pembinaan di luar sistem peradilan pidana dengan mengikutsertakan masyarakat luas. Kesimpulan atas kajian komparasi impmenatasi diatas dapat dianalisa sebagai berikut: a) Pada umumnya pihak penyidikan (kepolisian) berwenang penuh untuk mengimplementasikan ide diversi, sedangkan pihak penuntut umum terdapat negara yang memberikan penundaan penuntutan dan ada pula yang tidak memberikan memberikan kewenangan penuntut umum untuk melakukan diversi; b) Terdapat syaratsyarat pada umumnya dapat diterima sebagai syarat implementasi diversi seperti tindak pidana yang dilakukan pembinaan kedepan, tidak membahayakan masyarakat, korban telah memaafkan dan menerima ganti rugi, pelaku anak sanggup dan setuju untuk dilakukan pembinaan maupun cukup dengan peringatan formal dan informal; c) Implementasi diversi tahap pemeriksaan pengadilan pada umumnya dalam bentuk penangguhan penjatuhan pidana (suspended of execution) yang merupakan implementasi diversi dalam tahapan pemeriksaan pengadilan dan tahapa pelaksnaan putusan; d) Terdapat variasi ketentuan diversi diberbagai negara antara lain: 1) Terintergrasinya dalam KUHP yaitu di negara Cina; 2) Terintergrasinya 
dalam KUHAP yaitu di negara Jepang; 3) Diatur dalam Undang-undang Peradilan Anak yaitu

di negara Australia dan Indonesia.

Tabel 2. Perbandingan Impementasi Diversi Australia, Jepang, Cina, dan Indonesia

\begin{tabular}{|c|c|c|c|c|}
\hline \multirow{2}{*}{ Negara } & \multicolumn{4}{|c|}{$\begin{array}{l}\text { Tahapan-tahapan Sistem Peradilan Pidana Anak } \\
\text { dan Bentuk-bentuk diversi }\end{array}$} \\
\hline & Penyidikan & Penuntutan & $\begin{array}{l}\text { Pemeriksaan } \\
\text { Pengadilan }\end{array}$ & $\begin{array}{l}\text { Pelaksanaan } \\
\text { Putusan }\end{array}$ \\
\hline Australia & $\begin{array}{l}\text { Polisi melakukan peringatan } \\
\text { informal dengan teguran lisan } \\
\text { dan formal dialkukan dengan } \\
\text { media conference merupakan } \\
\text { tindak pidana ringan dan } \\
\text { permohonan maaf pada } \\
\text { korban dang anti rugi }\end{array}$ & Tidak ada & Tidak ada & Tidak ada \\
\hline Jepang & $\begin{array}{l}\text { Polisi dapat melakukan } \\
\text { menghentikan perkara bila: a) } \\
\text { Tindak pidana terhadap harta } \\
\text { dan tindak pidana ringan; b) } \\
\text { Tersangka sunguh-sungguh } \\
\text { menyesal; c) Tersangka telah } \\
\text { memberi ganti rugi; d) Korban } \\
\text { telah memaafkan si tersangka }\end{array}$ & $\begin{array}{l}\text { Jaksa berwenang } \\
\text { menunda penuntutan } \\
\text { (suspension of } \\
\text { prosecution) dengan } \\
\text { melihat faktor-faktor: } \\
\text { a) Karakteristik } \\
\text { usia, dan keadaan } \\
\text { si pelaku; b) Berat } \\
\text { ringannya tindak } \\
\text { pidana; c) Keadaan } \\
\text { akibat tindak pidana }\end{array}$ & Tidak ada & $\begin{array}{l}\text { Suspention of } \\
\text { execution of } \\
\text { setence }\end{array}$ \\
\hline Cina & $\begin{array}{l}\text { Polisi memberikan peringatan } \\
\text { atau memjatuhkan sejumlah } \\
\text { denda, maka perkara tidak } \\
\text { dilakukan penuntutan }\end{array}$ & Tidak ada & $\begin{array}{l}\text { Suspension of } \\
\text { sentence dilakukan } \\
\text { melihat keadaan } \\
\text { dan perbuatan } \\
\text { tidak akan } \\
\text { membehayakan di } \\
\text { masa mendatang } \\
\end{array}$ & Tidak ada \\
\hline Indonesia & $\begin{array}{l}\text { Polisi melakukan diversi } \\
\text { sesuai dengan Pasal } 9 \\
\text { dengan mempertimbangkan } \\
\text { kategori tindak pidana, } \\
\text { umur anak. Hasil penelitian } \\
\text { masyarakat, dukungan } \\
\text { lingkungan keluarga dan } \\
\text { masyarakat }\end{array}$ & $\begin{array}{l}\text { Penuntut Umum } \\
\text { melakukan diversi } \\
\text { sesuai dengan } \\
\text { Pasal } 9 \text { dengan } \\
\text { mempertimbangkan } \\
\text { kategori tindak } \\
\text { pidana, umur anak. } \\
\text { Hasil penelitian } \\
\text { masyarakat, } \\
\text { dukungan lingkungan } \\
\text { keluarga dan } \\
\text { masyarakat }\end{array}$ & $\begin{array}{l}\text { Hakim melakukan } \\
\text { diversi sesuai } \\
\text { dengan Pasal } \\
9 \text { dengan } \\
\text { mempertimbangkan } \\
\text { kategori tindak } \\
\text { pidana, umur anak. } \\
\text { Hasil penelitian } \\
\text { masyarakat, } \\
\text { dukungan } \\
\text { lingkungan keluarga } \\
\text { dan masyarakat }\end{array}$ & Tidak ada \\
\hline
\end{tabular}




\section{Implementasi Diversi Dalam Penanggulangan Tindak Pidana Anak}

Pelaksanaan kebijakan pemidanaan dalam bentuk diversi di implementasikan melalui tiga tahapan: Pertama, Diversi tahap penyidikan, merupakan tahap awal dari proses peradilan pidana. Dalam tahap ini dimungkinkan penyidik tidak melanjutkan tindak pidana kedalam proses peradilan pidana. Oleh karena itu tahap ini merupakan tahap yang paling strategis untuk memediasikan tindak pidana tertentu guna menghindari proses peradilan pidana dengan pencarian solusi yang menguntungkan semua pihak pelaku maupun korban tindak pidana. Penangkapan terhadap anakdilakukan guna kepentingan penyidikan, penyidikan yang dilakukan harus dikoordinasikan denganPenuntut Umum dalam waktu paling lama 1x24 jam (satu kali dua puluh empat jam) sejak dimulainya penyidikan. Koordinasi tersebut dimaksudkan untuk memberi petunjuk dan visi agar kelengkapan berkas dapat segera terpenuhi secara formal dan materiil, bertujuan supaya anak tidak dirugikan dalam tahapan berikutnya. Anak yang ditangkap wajib ditempatkan dalam ruang pelayanan khusus Anak, dalam hal ruang pelayanan khusus Anak belum ada di wilayah yang bersangkutan, Anak dititipkan di LPKS. Undang-Undang Sistem Peradilan Pidana Anak menegaskan bahwa penangkapan terhadap anak wajib dilakukan secara manusiawi dengan memerhatikan kebutuhan sesuai dengan umurnya dan seluruh biaya bagi setiap Anak yang ditempatkan di LPKS dibebankan pada anggaran kementerian yang menyelenggarakan urusan pemerintahan di bidang sosial. Pejabat yang melakukan penangkapan terhadap anak wajib memberitahukan kepada Anak dan orang tua/Wali mengenai hak memperoleh bantuan hukum,dan untuk menjaga proses tetap berjalan sesuai hukum, dalam hal pejabat tidak melakukan pemberitahuan sebagaimana yang mestinya, maka penangkapan terhadap Anak batal demi hukum.

Penahanan terhadap anak tidak boleh dilakukan jika Anak memperoleh jaminan dari orangtua/Wali dan/atau lembaga (lembaga, baik pemerintah maupun swasta, dibidang kesejahteraan sosial Anak, antara lain panti asuhan, dan panti rehabilitasi) bahwa Anak tidak akan melarikan diri, tidak akan menghilangkan atau merusak barang bukti, dan/atau tidak akan mengulangi tindak pidana. Berdasarkan pasal 32 ayat (2) Undang-Undang Sistem Peradilan Pidana Anak, penahanan terhadap Anak hanya dapat dilakukan dengan syarat yang harus dinyatakan secara tegas dalam surat perintah penahan, bahwa: a.Anak telah berumur 14 (empat belas) tahun atau lebih; dan b.diduga melakukan tindak pidana dengan ancaman pidana penjara 7(tujuh) tahun atau lebih. Undang-Undang ini juga menyebutkan bahwa selama anak ditahan, kebutuhan jasmani, rohani dan sosial anak harus terpenuhi. Untuk melindungi keamanan anak, dapat dilakukan penempatan anak di LPKS, sehingga apabila tidak terdapat LPAS pada daerah dimana Anak ditahan, penahanan dapat dilakukan di LPKS setempat. Sayangnya Undang-Undang ini tidak cukup mengatur jika penyidik berkeras melakukan penahanan meski sudah ada jaminan terhadap anak sebagai yang disyaratkan dalam Pasal 32 ayat (1) Undang-Undang Sistem Peradilan Pidana Anak. Jangka waktu penahanan bagi anak diajukan oleh instansi yang berwenanang dimasing-masing tahapan, baik penyidikan, penuntutan dan pemeriksaan di ruang sidang juga dalam tahapan upaya hukum mulai dari banding sampai dengan kasasi.

Pidana peringatan merupakan pidana ringan yang tidak mengakibatkan pembatasan kebebasan anak. Pidana dengan syarat dapat dijatuhkan oleh Hakim dalam hal pidana penjara yang dijatuhkan paling lama 2 (dua) tahun, dalam Putusan pengadilan mengenai pidana dengan syarat ditentukan syarat umum dan syarat khusus. Syarat umum adalah Anak tidak akan melakukan tindak pidana lagi selama menjalani masa pidana dengan syarat, sedangkan syarat khusus adalah untuk melakukan atau tidak melakukan hal tertentu yang ditetapkan dalam Putusan hakim dengan tetap memperhatikan kebebasan Anak. 


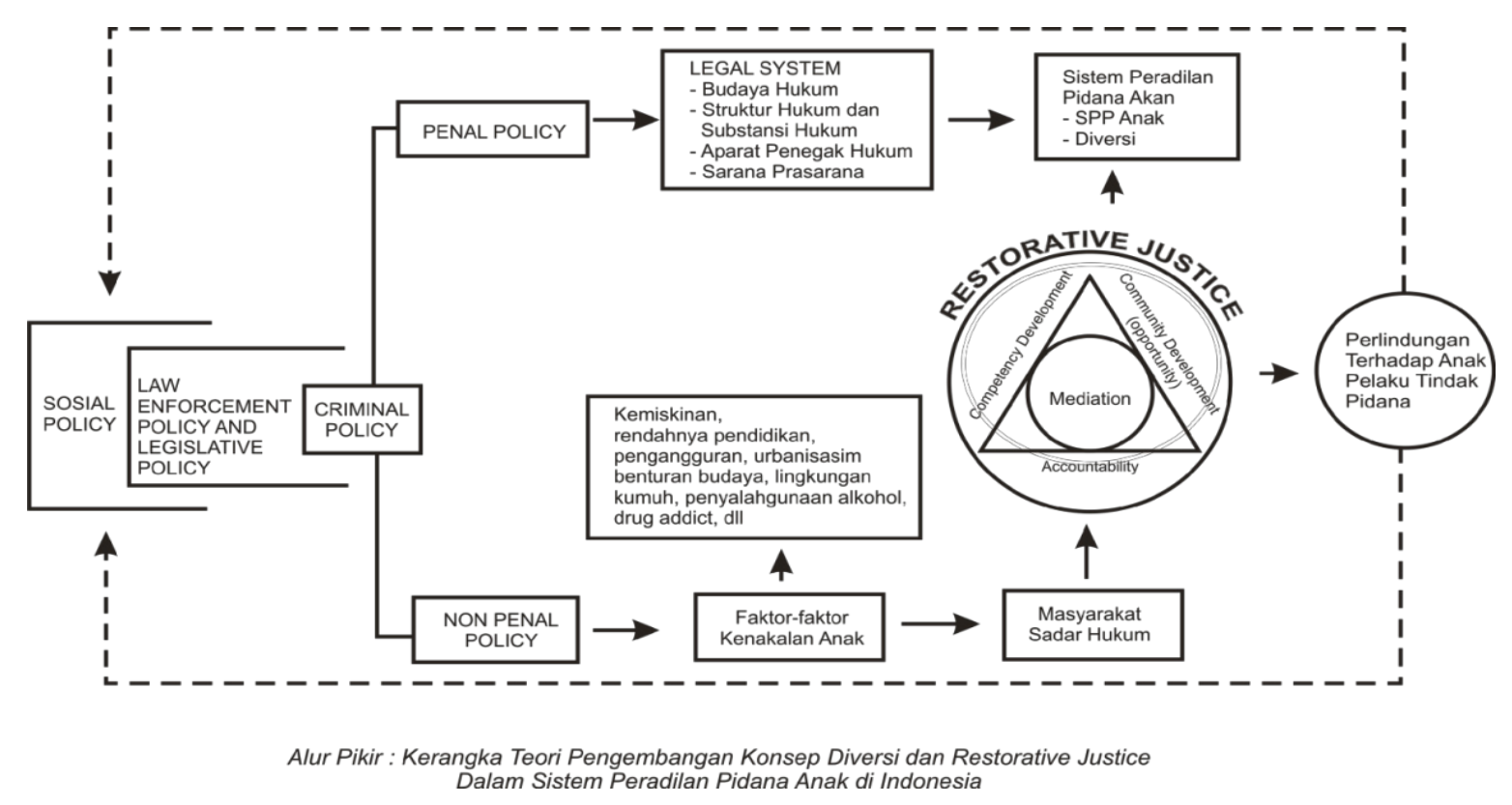

Masa pidana dengan syarat khusus lebih lama daripada masa pidana dengan syarat umum, dimana Jangka waktu masa pidana dengan syarat paling lama 3(tiga) tahun. Pidana pelayanan masyarakat merupakan pidana yang dimaksudkan untuk mendidik Anak dengan meningkatkan kepeduliannya pada kegiatan kemasyarakatan yang positif. Jika Anak tidak memenuhi seluruh atau sebagian kewajiban dalam menjalankan pidana pelayanan masyarakat tanpa alasan yang sah, pejabat pembina dapat mengusulkan kepada hakim pengawas untuk memerintahkan Anak tersebut mengulangi seluruh atau sebagian pidana pelayanan masyarakat yang dikenakan terhadapnya. Pidana pelayanan masyarakat ini dijatuhkan paling singkat 7 (tujuh) jam dan paling lama 120 (seratus dua puluh) jam. Selain itu ada yang disebut dengan pidana pelatihan kerja dilaksanakan di lembaga yang melaksanakan pelatihan kerja yang sesuai dengan usia Anak. Pidana pelatihan kerja ini dikenakan paling singkat 3 (tiga) bulan dan paling lama 1 (satu) tahun. Adalagi Pidana pembinaan di dalam lembaga, dilakukan di tempat pelatihan kerja atau lembaga pembinaan yang diselenggarakan, baik oleh pemerintah maupun swasta dalam jangka waktu paling singkat 3(tiga) bulan dan paling lama 24 (dua puluh empat) bulan. Pidana penjara diletakkan dalam porsi paling terakhir dalam UndangUndang Sistem Peradilan Pidana Anak, hal ini tercermin berdasarkan pengaturan Pasal 81 ayat(5), yang menyatakan bahwa pidana penjara terhadap Anak hanya digunakan sebagai upaya terakhir. Pidana pembatasan kebebasan diberlakukan dalam hal Anak melakukan tindak pidana berat atau tindak pidana yang disertai dengan kekerasan dan Anak dijatuhi pidana penjara di LPKA apabila keadaan dan perbuatan anak akan membahayakan masyarakat. Pidana penjara yang dapat dijatuhkan kepada Anak paling lama $1 / 2$ (satu perdua) dari maksimum ancaman pidana penjara bagi orang dewasa serta minimum khusus pidana penjara tidak berlaku terhadap anak.

Kedua, Diversi ditingkat penuntutan, dalam tahapan ini seorang Jaksa Penuntut Umum dengan mempelajari tindak pidana yang dilakukan oleh pelaku berdasarkan kriteriakriteria tertentu, dapat menawarkan mediasi kepada korban dan pelaku tindak pidana. Mediasi dilakukan berdasarkan persetujuan secara suka rela dari pelaku dan korban tindak pidana. Jika kedua pihak menyetujui untuk dilakukan mediasi, maka persetujuan untuk mediasi diberikan kepada jaksa penuntut umum.Jaksa penuntut dapat berposisi sebagai mediator maupun melakukan penunjukan mediator yang bersertifikasi. Mediator kemduian 
mempertemukan pihak pelaku dan korban tindak pidana. Pelaksanaan proses mediasi dilakukan secara rahasia, dalam arti semua peristiwa yang muncul selama mediasi tidak dapat dipublikasikan oleh semua pihak yang terlibat. Dalam mediasi penal tidak mencapai kesepakatan, maka perkara pidana akan dilanjutkan dengan pemeriksaan di sidang pengadilan dengan dilakukan penuntutan terhadap tindak pidananya. Dalam hal ini mediator tidak dapat bersaksi atas tidak tercapainya kesepakatan mediasi maupun atas segala sesuatu yang terjadi selama proses mediasi. Jika mediasi mencapai kesepakatan damai yang diterima oleh semua pihak, maka akta kesepakatan berlaku sebagai putusan yang final dan tidak dapat diadakan penuntutan, sehingga dapat berfungsi sebagai alasan penghapus tuntutan.

Ketiga, Diversi Tahap Pengadilan, mediasi penal yang dilakukan tahap ini adalah setelah perkara dilimpahkan ke pengadilan oleh penuntut umum. Dalam mediasi pada tahap ini hakim menawarkan alternatif penyelesaian perkara dengan cara perdamaian kepada para pihak yaitu pelaku pidana dan pihak korban sebelum dilakukan proses pemeriksaan didepan sidang pengadilan dengan melihat kriteria tindak pidana yang dilakukan oleh terdakwa. Mediasi ini jika mencapai kesepakatan maka hasilnya dapat digunakan sebagai alasan untuk menghapuskan menjalankan pidana bagi pelaku tindak pidana. Mediator pada tahap ini bisa dilakukan oleh hakim atau mediator dari luar pengadilan yang telah sertifikasi dan pelatihan. Mediasi ini adalah gabungan dari model victim-offender mediation dan reparation negotiation progammes. Hakim setelah mempelajari kasus dan tindak pidana yang dilakukan oleh terdakwa, dapat menawarkan mediasi penal sebagai alternative penyelesaian perkara dengan perdamaian para pihak. Jika para pihak menyetujui maka diadakan persetujuan secara suka rela untuk mengikuti penyelesaian perkara dengan cara mediasi baik oleh pelaku maupun oleh korban. Hakim dapat bertindak sebagai mediator ataupun mediator di luar pengadilan yang telah memenuhi syarat dan bersertifikasi. Mediasi mempertemukan pihak pelaku dan korban, pada kesempatan ini dilakukan rekonsiliasi antara korban dan pelaku serta dilakukan pembayaran ganti kerugian yang diderita korban. Mediasi penal dilakukan berdasarkan prinsip rahasia, sehingga segala peristiwa yang terjadi dan segala pernyataan yang muncul dalam proses mediasi harus dirahasikan oleh para pihak termasuk mediator. Jika mediasi tidak mencapai kesepakatan maka proses pemeriksaan di muka pengadilan akan dilanjutkan sebagaimana mestinya. Jika tercapai kesepakatan dimana para pihak saling menerima hasil kesepakatan (rekonsiliasi) dan disepakati pembayaran ganti kerugian oleh pelaku kepada korban, maka hasil kesepakatan yang dituangkan dalam akta kesepakatan menjadi berkekuatan tetap sebagaimana putusan pengadilan dan bersifat final, sehingga pelaku tidak dapat dituntut dan diadili kembali dalam proses peradilan pidana.

\section{Kesimpulan}

Berdasarkan pembahasan di atas dapat disimpulkan bahwa diversi merupakan salah satu alterbatif dalam penanganan anak yang berkonflik dengan hukum yang secara filosofi sesuai dengan nilai-nilai pancasila yang mengandung prinsip pemidanaan secara proposional dan asas kepentingan terbaik bagi anak (the best interestof the child). Dari sisi implementasi, pada umumnya pihak penyidikan (kepolisian) berwenang penuh untuk mengimplementasikan ide diversi, sedangkan pihak penuntut umum dapat memberikan penundaan penuntutan. Terdapat syarat-syarat mengimplementasikan diversi seperti tindak pidana yang dilakukan pembinaan, tidak membahayakan masyarakat, korban telah memaafkan dan menerima ganti rugi, pelaku anak sanggup dan setuju untuk dilakukan pembinaan maupun cukup dengan peringatan formal dan informal. 


\section{DAFTAR PUSTAKA}

Undang-Undang Nomor 11 Tahun 2012 tentang Sistem Peradilan Pidana Anak

Herlina, Apong. Perlindungan Terhadap Anak Yang Berhadapan Dengan Hukum Dengan Manual Pelatihan Untuk Polisi. Jakarta: Polri dan Unicef. 2004

Nawawi, Barda. Beberapa Aspek Kebijakan Penegakan dan Pengembangan Hukum Pidana. Bandung: P.T Citra Aditya Bakti. 1999

Data Terakhir Klasifikasi Narapidana Anak Perkanwil (Online) (dapat diakses di http://smslap.ditjenpas.go.id/public/ arl/current/monthly/year/2015/month/1, tanggal 15 Januari 2015).

Tjokrowasito, Mardiharto dkk. Background Study RPJMN 2015-2019 Bidang Pembangunan
Hukum Nasional. Jakarta: Bappenas. 2013

Dewi, DS. dan Fatahillah A. Syukur, Mediasi Penal: Penerapan Restorative Justice di Pengadilan Anak Indonesia. Depok: Indie Publishing. 2011

Supeno, Hadi. Kriminalisasi Anak Tawaran Gagasan Radikal Peradilan Anak Tanpa Pemidanaan. Jakarta: Gramedia Pustaka Utama. 2010

Marliana. Peradilan Pidana Anak di Indonesia Pengembangan Konsep Diversi dan Restoratif Justice. Bandung: Refika Aditama, 2012

Umam, Khotibul. Penyelesaian Sengketa di Luar Pengadilan. Yogyakarta : Pustaka Yustisia, 2010. 